\title{
Hell of the bloody pond and the rebirth of women in the paradise
}

\section{Shunshō MANABE}

Since ancient time the status of woman was esteemed low. It is said, she can not become the Buddha, there is no woman in the pure land. It is said in the Devadatta varga of the Lotus sūtra that woman has 5 obstacles for which she can not become Brahmā devarāja, Śakra, lord of gods, māra-rāja, Cakravartin and the Buddha. Many scriptures, and treatises say that woman was called the messenger of the hell, one who has broken the seed of the Buddha, the root of destroying the country, one whose substance is disbelief, one who has 5 obstcles and 3 obediences, one who can not become the Buddha. She was excluded from the deliverance. Such view and the doctrine of the Mahāyāna Buddhism that every one can become the Buddha are contradictory. The Amitāyus sūtra preaches the vow of Amilābha Buddha that woman can be reborn in the pure land (the 35th vow). The Devadatta-varga of the Lotus Sütra Preaches that 8 year girl of a Nāga became the Buddha. Nāga's becoming the Buddha has an important meaning as the foundation of woman's becoming the Buddha. It broke the negative view of woman in many scriptures. It manifested the view of the Lotus sutra that all the women can become the Buddha. The theory of the school of Sukhāvati in the Tendai sect influenced very much on the motif of the rebirth of women in the pure land in mid-ancient and mediaeval literature.

It is a feature of Buddhism in the Kamakura period that preaches that woman becomes the Buddha and is born in the pure land. Nichiren esteemed a nāga girl becoming the Buddha preached in the Lotus sūtra as the realization of woman becoming the Buddha. He said "if it is not becoming the Buddha by recollecting the 3000 worlds in one idea, it is 
Hell of the bloody pond and the rebirth of women (S. MANABE) ( 35 ) becoming the Buddha only nominal and that has no substance. A nāgi's becoming the Buddha demonstrate that woman in later generation will become the Buddha or will be reborn in the pure land. Woman becoming the Buddha is a doctrine of the Lotus sūtra that teaches all the sentient beings can become the Buddha, one of the reasons why the woman can not become the Buddha is 5 obstacles and 3 obediences. The 5 obstacles is preached in the Majjhima-nikāya. 28, Ekottara-āgama, 28 and Devadatta-varga of the Lotus Sütra. A woman has 5 obstacles, that she can not become Brahmā devarāja, Śakra, lord of gods, māra-king, cakravartin, and the Buddha. The three obediences is preached in the Manu-smrti in India, and "the Givai" is China, that a woman should obey her parents when young, obey her husband when she is married, an obey her children when she is old, These are the fundamental obstacles of the female sex for becoming the Buddha. It was supposed that the female sex can not become the Buddha unless she is transformed into a male. The idea of discrimination of woman in India was introduced in Japan and was emphasized until it sometimes revalled with the thought of woman becoming the Buddha.

\section{The prohibition of woman}

The woman was not admitted to enter a specific monastery or sacred place, because a woman is defiled and obstructs the religious practices of a male priests. The precinct was indicated by a stone of boundary. The prohibition was prectised at Hieizan, Kōyasan, and Kimpusen and others. The fact can be found in the records and literary works in the Heian period, The term is found since the Muromachi period. A woman is not admitted to enter the inner precinct of the main temple. It is a sort of prohibition. Dōgen, Hōnen and Sonkaku criticized the prohibition of the woman and denied it.

Women's hall is a hall where women stayed to recite the scriptures and practised the reading of the scripture and reciting the Buddha's name outside the precinet of the monastery where non-admittance of woman was practised. Women's halls were established in the seven entrances to 
( 36 ) Hell of the bloody pond and the rebirth of women (S. MANABE)

Kōyasan. The women were not admitted to proceed further inside. The Hanatsumi-dō at Higashi Sakamoto guchi, Hieizan was opened only on the 8th April. Women were admitted as far as the hall. This day was the birthday of the Buddha. The hall was decorated with the flowers of azalea, and the abhisinca (sprinkling of water on the figure of the Buddha) was performed. The Hanatsumi-dō was woman's hall once a year.

\section{What is the hell of bloody pond?}

The thought of the hell of the bloody pond-that wamenfall in it because of the defilement of blood was given rise by the Ketsubonkyo consisting of only 420 letters. I have already related that female priests from Kumano played a big part. They explained on the origin of the Ketsubonkyō by means of maṇdalas and picture scrolls for the sake of women in the society. It was natural that the Ketsubonkyō preached for the deliverance of women was propagated in every nook of the country. This "Ketsubonkyo" is a scripture to save women who tall in the hell because of defilement of blood. Property it is "the Bussetsu-Daizōshōgyōketsubon-kyō. It seems to have been pravalent in the period of Ming and Ch'ing in China. The scripture belonged to Buddhism, Taoism and a special association. The content has various topics. It is regarded to have been brought to Japan in the 15th century, but exact time is unknown. The contenu of the Japanese version of the Ketsubon-kyō has changed the quality as the time elapsed to the modern period. In the beginning of the period the hell of the bloody pond was regarded to be the place where women fall because of the defilement of the blood in the case of the birth. In the modern period it was told that they fall in the hell because of the blood of child birth and the menses. Further they were regarded to fall there because of the defilement of the menstruation. The form of the belief in the Ketsubon-Kyō is classified in to three.

(1) The belief in the Ketsubonkyō as a talisman. (Talisman drunk for evading disaster and praying)

(2) The belief in the Ketsubonkyo for offering to the dead.

(3) The belief in the Ketsubonkyo for praying for being reborn in the 
Hell of the bloody pond and the rebirth of women (S. MANABE) ( 37 )

pure land

The 1st belief is known as the prayer for the easy birth and for evading defilement in the assembly of giving the discipline. The second belief is known as the offering of the Ketsubon-kyō in the ceremony of giving offering to hungry pretas and putting the scripture in a coffin and the third belief is known as the great Abhișeka at Nunobashi in Tateyama and the transcription of the Ketsubon-kyō scripture. When we consider on the hell and why they fall in the hell, an interesting point can be pointed out. Genshin taught in "the ōjō-yōshū" that a man gets a punishment in accordance with the crime committed. It was punitive suffering in the hell. Here one does not fall in a hell because of the crime committed in his life. But he fall in the hell because the blood streamed out of the body defiler Gods and Buddhas. The condition why one suffers the punishment is the defilement of blood that is inevitable for any woman. Originally the nuns of Kumano were the nuns who recommended the worship of Kumano. In the Kamakura period they degraded as the result of the deterioration of the belief in Kumano. The nuns of Kumano came on the stage in the essays since the beginning of the Edo period. We have scarcelly any material for the period before it as the Mediaeval age sets in, a special form as a talking feat was made. Eminent priests explained the Buddhist picture in the Kamakura and Nambokuchō period. Many priests in lower grade and laymen were active in teaching Buddhism. Such action was popularized. Folks had the trend to enjoy the sermon that had the manner of amusement. The sermon had the phase of amusement. They made more and more amusement as it urged the development of Buddhist entertainment. In the modern period women appeared among the interpreters of popular explanation. "The Tōkaidōmeishoki" (account of the noted places along Tōkaidō route) by Asai Ryōi published in the 2nd year of Manji (1859) has the factual condition of the Kumano nuns in those days. There was a mandala of Tateyama to deliver women. There was a Abhișeka meeting of Nunobashi. This ceremony took place in the monastery of Tateyama Ashikura until the 
( 38 ) Hell of the bloody pond and the rebirth of women (S. MANABE) end of the Tokugawa period.

The picture is the 10 spheres in mind form Kumano. Kept in Daienji, 17 th century. $148 \mathrm{~cm} \times 130 \mathrm{~cm}$ About 20 works of the picture of the ten spheres in mind are confirmed. The manner of representation is relatively fixed except the fiction of Rokudō-chinkōji. The work of Daienji (city of Tsu, Miyé prefectue) is regarded to be made in the begining of the Edo period. It has a typical way of representation. Compared with the work of Rokudō-chinkōji, the stages of human life became semi-circular, Torii is arranged to each of the 6 ways. Such is the difference.

The picture of the 10 spheres in the mind was contrived by JiunJunshiki in the Sung Period in China, entitled "the Enton-Kanshin-Jippōkai$\mathrm{zu}^{*}$. It shows the six ways of illusion and the 4 way of enlightenment (the Buddha, Bodhisattva Pratyeka-Buddha th șrāvnka) are added. The ten spheres are in our mind. Various motifs were added in our country. It collected the belief as the picture of the hell and the paradise.

〈Key Words〉 血の池地獄, 女人往生, 血盆經, 熊野比丘尼, 立山曼茶羅

(Lecturer, University of the Sacred Heart)

会則改定のお知らせ

平成 5 年 5 月 22 日の評議員会で会則が改定されております。会員 諸氏のご協力をお願いいたします。

（新会則は本誌296頁以下に揭載されております。）

日本印度学仏教学会 